\title{
Significant Benefits of Nanoparticles Containing a Necrosis Inhibitor on Mice Testicular Tissue Autografts Outcomes
}

\author{
Federico Del Vento ${ }^{1}$, Maxime Vermeulen ${ }^{1}$ (D), Bernard Ucakar ${ }^{2}$, Jonathan Poels ${ }^{1,3}$, \\ Anne des Rieux ${ }^{2}$ and Christine Wyns $1,3, *$ (D) \\ 1 Gynecology-Andrology Unit, Medical School, Institute of Experimental and Clinical Research, Catholic \\ University of Louvain, UCLouvain, 1200 Brussels, Belgium; federico.delvento@uclouvain.be (F.D.V.); \\ vermeulen.maxime@live.be (M.V.); jonathan.poels@uclouvain.be (J.P.) \\ 2 Advanced Drug Delivery and Biomaterials Unit, Louvain Drug Research Institute, Catholic University of \\ Louvain, UCLouvain, 1200 Brussels, Belgium; bernard.ucakar@uclouvain.be (B.U.); \\ anne.desrieux@uclouvain.be (A.d.R.) \\ 3 Department of Gynecology-Andrology, Saint-Luc University Hospital, 1200 Brussels, Belgium \\ * Correspondence: christine.wyns@uclouvain.be
}

Received: 26 October 2019; Accepted: 18 November 2019; Published: 20 November 2019

check for updates

\begin{abstract}
Fertility preservation for prepubertal boys relies exclusively on cryopreservation of immature testicular tissue (ITT) containing spermatogonia as the only cells with reproductive potential. Preclinical studies that used a nude mice model to evaluate the development of human transplanted ITT were characterized by important spermatogonial loss. We hypothesized that the encapsulation of testicular tissue in an alginate matrix supplemented with nanoparticles containing a necrosis inhibitor (NECINH-NPS) would improve tissue integrity and germ cells' survival in grafts. We performed orthotopic autotransplantation of $1 \mathrm{~mm}^{3}$ testicular tissue fragments recovered form mice (aged 4-5 weeks). Fragments were either non-encapsulated, encapsulated in an alginate matrix, or encapsulated in an alginate matrix containing NECINH-NPs. Grafts were recovered 5- and 21-days post-transplantation. We evaluated tissue integrity (hematoxylin-eosin staining), germ cells survival (immunohistochemistry for promyelocytic leukemia zinc-finger, VASA, and protein-boule-like), apoptosis (immunohistochemistry for active-caspase 3), and lipid peroxidation (immunohistochemistry for malondialdehyde). NECINH-NPs significantly improved testicular tissue integrity and germ cells' survival after 21 days. Oxidative stress was reduced after 5 days, regardless of nanoparticle incorporation. No effect on caspase-dependent apoptosis was observed. In conclusion, NECINH-NPs in an alginate matrix significantly improved tissue integrity and germ cells' survival in grafts with the perspective of higher reproductive outcomes.
\end{abstract}

Keywords: necrosis inhibitor; nanoparticles; prepubertal testicular tissue; transplantation; fertility preservation; spermatogonia; prepubertal boys; necrosis; tissue engineering; male fertility

\section{Introduction}

During the last decades, the improvement of oncological therapies increased cancer survival rates for pediatric patients in Europe [1]. However, one potential side effect of chemotherapy and radiotherapy is a permanent loss of fertility [2]. For prepubertal boys facing such treatments, the only option for fertility preservation is cryobanking of immature testicular tissue (ITT) containing spermatogonia as the only cells with reproductive potential, with the perspective of future autologous use of banked tissue $[3,4]$. 
To respond to a concern that deeply compromises the quality of life after cancer, several clinics have initiated a fertility preservation program for the male pediatric population [5-7]. The procedure consists of testicular sampling and cryopreservation of small testicular fragments. The satisfaction of patients and parents has been surveyed, and the results showed that acceptance rates reached $74 \%$ when a multidisciplinary care pathway was organized [8].

To restore fertility once the patient is cured, several strategies using patient's own frozen-thawed ITT have been proposed, such as autotransplantation of whole tissue pieces [9] or spermatogonial stem cells [10], in vitro maturation (for review see [11]), and testicular organoids generation for in vivo or in vitro use [12-14].

Based on ITT transplantation outcomes in several animal species (for review see, [15]) and on the very recent achievement of a live birth in non-human primates [16], transplantation of the cryostored testicular tissue back to the cured patient appears to be the most promising strategy to offer these patients a chance to father their own genetic child.

With regard to human ITT, xenotransplantation to castrated nude mice showed spermatogonia's ability to survive, proliferate, and even differentiate up to the stage of pachytene spermatocyte [17], although complete spermatogenesis was not achieved. Besides an incomplete differentiation, all human ITT xenotransplantation experiments were characterized by a limited spermatogonial survival [17-22]. Hypoxia and oxidative stress were suggested to be responsible as the procedure of grafting is an avascular transplantation technique where no artificial anastomosis between the grafted fragment and the host vascular system is performed [9]. Such procedure exposes the grafted tissue to a period of hypoxia during the first 5 days (as demonstrated for xenotransplantation of ovarian tissue [23]), before its revascularization with neo-vessels sprouting from the grafted tissue and connecting with the vascular system of the host [24]. The consequent ischemia/reperfusion increases the production of radical oxygen species (ROS) $[25,26]$ that might harm testicular tissue and cells.

Considering the limited amounts of testicular tissue that can be cryostored for each patient and the scarcity of spermatogonia stem cells in the testis [27], our objective was to define a transplantation condition that would be the most efficient in terms of survival of spermatogonia. Several investigators have already assessed the impact of graft supplementation with various molecules or growth factors. Recent encouraging results were reported when 5 days in vitro culture step of human tissue with vascular endothelial growth-factor (VEGF) was performed before xenografting to the nude mice [22]. However, hormone supplementation with testosterone [21] or follicle-stimulating hormone (FSH) [20] and the use of antioxidant molecules [21] did not improve graft outcome. Hence, alternative approaches need to be investigated using both new molecules and alternative drug delivery strategies.

Tissue engineering techniques that combine biomaterials to protect testicular tissue and nanomedicines, providing localized and sustained drug delivery have been considered [28], and privileging local controlled delivery are important in the context of cancer as molecules acting as survival factors on distant tumor sites may have deleterious consequences for the patient [29].

In a previous study, we demonstrated that autologous transplantation of mice testicular tissue encapsulated in an alginate hydrogel resulted in a 2-fold increase of spermatogonial survival, a result that was suggested to be linked to the antioxidant properties of alginate. The addition of VEGF-loaded nanoparticles (NPs) to reduce the hypoxic period improved short-term angiogenesis but did not further increase spermatogonia survival [30].

We hypothesized that localized delivery of a necrosis inhibitor (NECINH) could be an alternative to improve testicular tissue graft outcomes. NecroX-5 $5^{\mathrm{TM}}$ was selected as a candidate molecule as it belongs to the family of indole derivative exerting anti-necrotic properties by scavenging mitochondrial reactive oxygen and nitrogen species [31]. As its anti-necrotic properties in the context of hypoxia/reoxygenation conditions were demonstrated in experiments on rodent hearts [32], we assumed that it could reduce the damages induced in testicular tissue fragments exposed to hypoxia-reoxygenation during the avascular transplantation procedure. We encapsulated NecroX-5 in poly(D,L-lactide-co-glycolide)/poly(ethylene glycol (PLGA/PEG) NPs in order to increase its solubility and to achieve a controlled, sustained, 
and localized release after its incorporation in a $1 \%$ alginate tissue embedding matrix. We evaluated the encapsulation efficiency and release profile of the NPs formulation, and the impact of NECINH supplementation was assessed both in vitro on mouse testicular tissue exposed for 21 days to hypoxia and in vivo after testicular tissue autotransplantation for 5 and 21 days.

\section{Results}

\subsection{Characterization of Nanoparticles}

NECINH NPs presented a size of $293+/-41 \mathrm{~nm}$, a polydispersity index (PDI) of $0.19+/-0.12$, and zeta potential of $-39+/-6 \mathrm{mV}$.

After 7 days of incubation, $64 \%$ of encapsulated NECINH was released without significant burst effect, and after 21days, the drug release was almost completed (Figure 1).

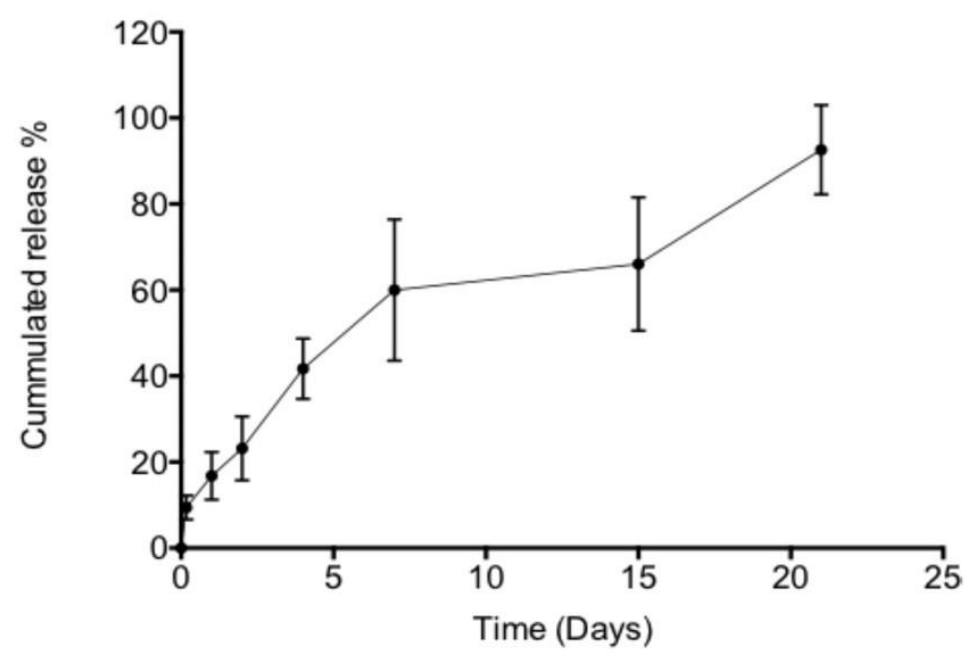

Figure 1. In vitro release of NECINH-nanoparticles (NPs) incorporated in $1 \%$ alginate hydrogel. Twenty-five microliters of NPs corresponding to $15.27 \mu \mathrm{g}$ of NECINH were incorporated in a $50 \mu \mathrm{l}$ alginate hydrogel and immersed in $40 \mathrm{mM} \mathrm{CaCl}_{2}$ PBS (Phosphate buffer saline) for 21 days at $37^{\circ} \mathrm{C}$. The release was evaluated over time by fluorimetry $(n=4)$.

\subsection{Impact of Nanoparticles Containing Necrosis Inhibitor Loaded in Alginate Hydrogel on Testicular} Fragments Exposed to Hypoxia In Vitro

Validation of the impact of hypoxia on lactate dehydrogenase (LDH) concentration measured in tissue culture supernatants is presented in the Supplementary Material (Figure S1). LDH concentration increased over time in testicular fragment culture medium in hypoxia, but no significant impact of supplementation with NECINH-NPs or encapsulation in alginate alone was observed (Figure 2). 


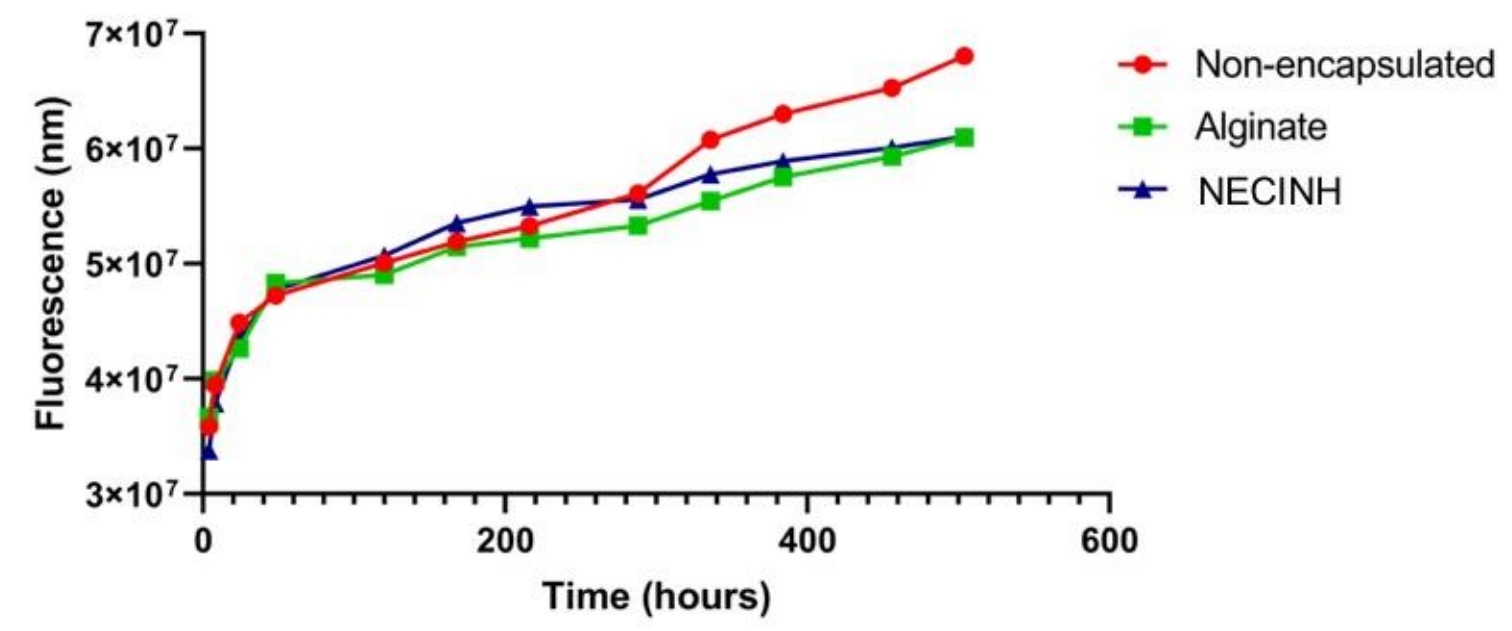

Figure 2. Impact of testicular fragment incorporation in NECINH nanoparticles-loaded alginate hydrogel on tissue necrosis when cultured in hypoxia. Cumulative values of fluorescence corresponding to the lactate dehydrogenase (LDH) measured in culture supernatants recovered every $48-72 \mathrm{~h}$.

We analyzed 2484 seminiferous tubule sections (STs), of which 1371 at 5 days (437 for non-encapsulated, 371 for encapsulation in alginate, and 563 for encapsulation in alginate with NPs) and 1113 STs at 21 days (314 for non-encapsulated, 267 for encapsulation in alginate, and 532 for encapsulation in alginate with NPs). Table 1 shows tissue integrity scores in the different groups of grafts. No STs were scored as intact (score 1). At 5 days, the majority of STs appeared satisfactory (Score 2) (89\% versus 11\% damaged (Score 3)) (Table 1).

Table 1. Impact of NECINH-nanoparticles (NPs)-loaded hydrogel on mice testicular tissue exposed to hypoxia $\left(1 \% \mathrm{O}_{2}\right)$ for 5 and 21 days. Results for tissue integrity are expressed as the mean percentage of seminiferous tubules for each integrity score and condition \pm standard deviation.

\begin{tabular}{cccc}
\hline $\mathbf{5}$ Days & Non-Encapsulated & Alginate & NECINH-NPs \\
\hline Score 2 & $93 \% \pm 5 \%$ & $87 \% \pm 14 \%$ & $88 \% \pm 8 \%$ \\
\hline Score 3 & $6 \% \pm 5 \%$ & $13 \% \pm 14 \%$ & $11 \% \pm 8 \%$ \\
\hline 21 Days & Non-Encapsulated & Alginate & NECINH-NPs \\
\hline Score 2 & $18 \% \pm 11 \%$ & $19 \% \pm 7$ & $20 \% \pm 1 \%$ \\
\hline Score 3 & $80 \% \pm 12$ & $80 \% \pm 7$ & $78 \pm 0.6 \%$ \\
\hline
\end{tabular}

At 21 days, this trend was reversed, showing a majority of seminiferous tubules sections presenting a score of 3 over a score of $2(80 \%$ versus $20 \%)$. No statistically significant difference was observed between the three groups (Figure 3). 


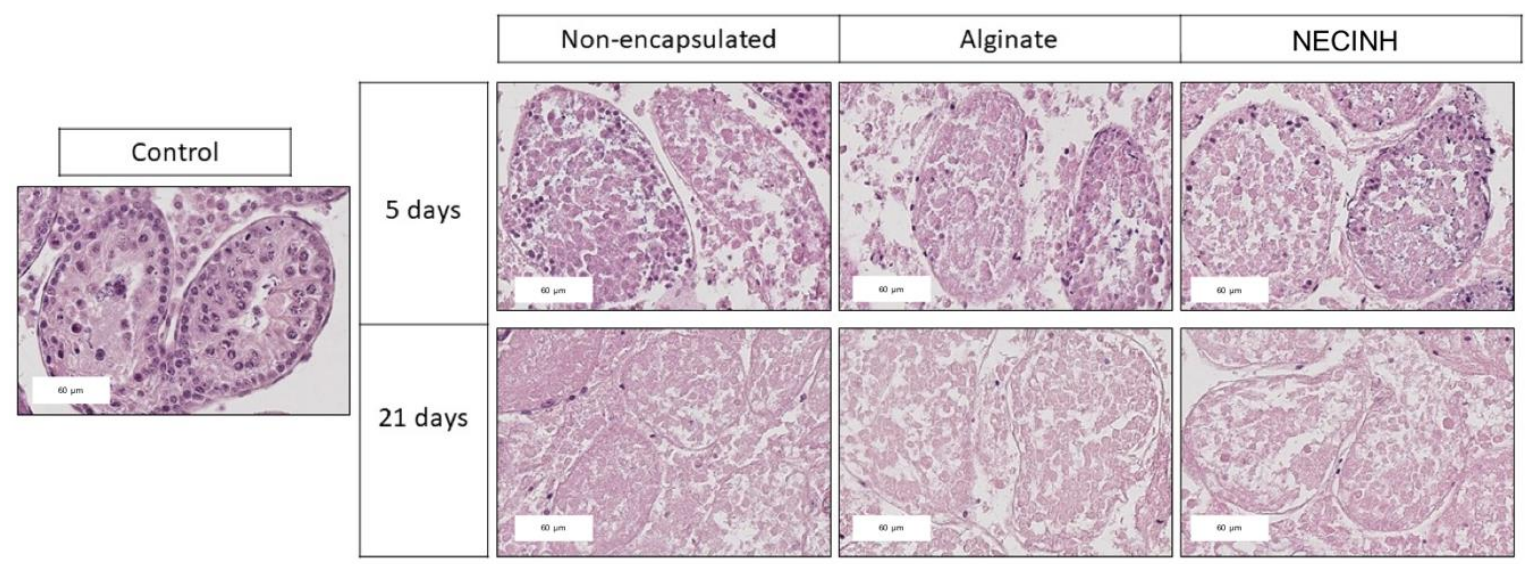

Figure 3. Impact of NECINH-nanoparticles-loaded hydrogel on mice testicular tissue exposed to hypoxia $\left(1 \% \mathrm{O}_{2}\right)$ and recovered after 5 or 21 days. Three conditions were compared for each timing (non-encapsulated, encapsulated in alginate, and encapsulated in alginate with NECINH NPs). Hematoxylin-eosin staining was used for the evaluation of STs (seminiferous tubule sections) morphology. Scale bar $=60 \mu \mathrm{m}$.

No undifferentiated spermatogonia identified by promyelocytic leukemia zinc finger (PLZF) staining was found in non-encapsulated tissue fragments after 21 days of culture, while rare PLZF-positive cells were observed in encapsulated tissues, whether it was supplemented with NECINH or not (Figure 4).
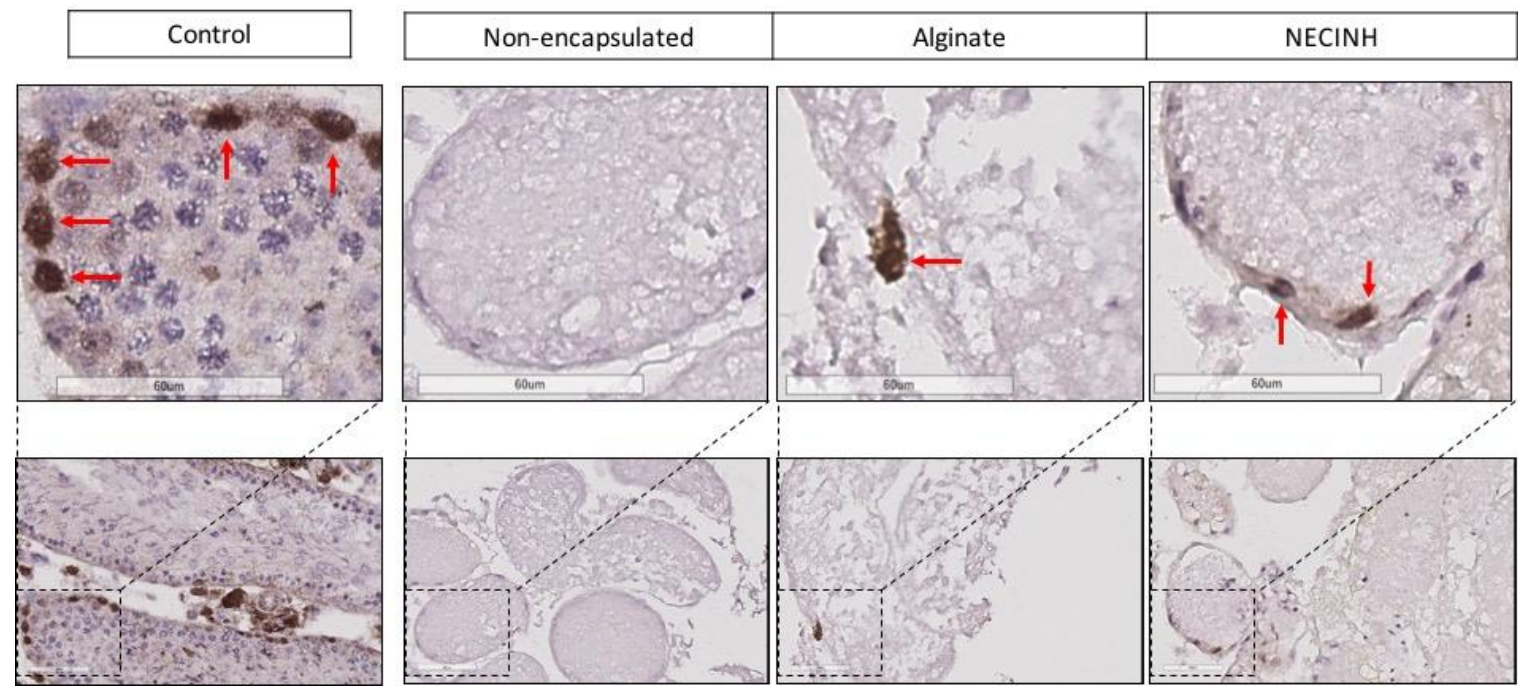

Figure 4. Impact of NECINH-nanoparticles-loaded hydrogel on mice testicular tissue exposed to hypoxia $\left(1 \% \mathrm{O}_{2}\right)$ for 21 days. Undifferentiated spermatogonial survival. Promyelocytic leukemia zinc finger (PLZF) + cells are highlighted by red arrows.

\subsection{Impact of NECINH-Nanoparticles-Loaded Alginate Hydrogel on Testicular Fragment In Vivo Viability}

\subsubsection{Tissue Integrity}

For the evaluation of tubular integrity and morphology of recovered tissue on hematoxylin-eosin stained slides (Figure 5), 2157 ST sections were analyzed after 5 days (529 for non-encapsulated tissue, 897 for encapsulation in alginate, and 731 for encapsulation in alginate loaded with NECINH NPs) and 2235 after 21 days (886 for non-encapsulated tissue, 420 for encapsulation in alginate, and 929 for encapsulation in alginate loaded with NECINH NPs). 

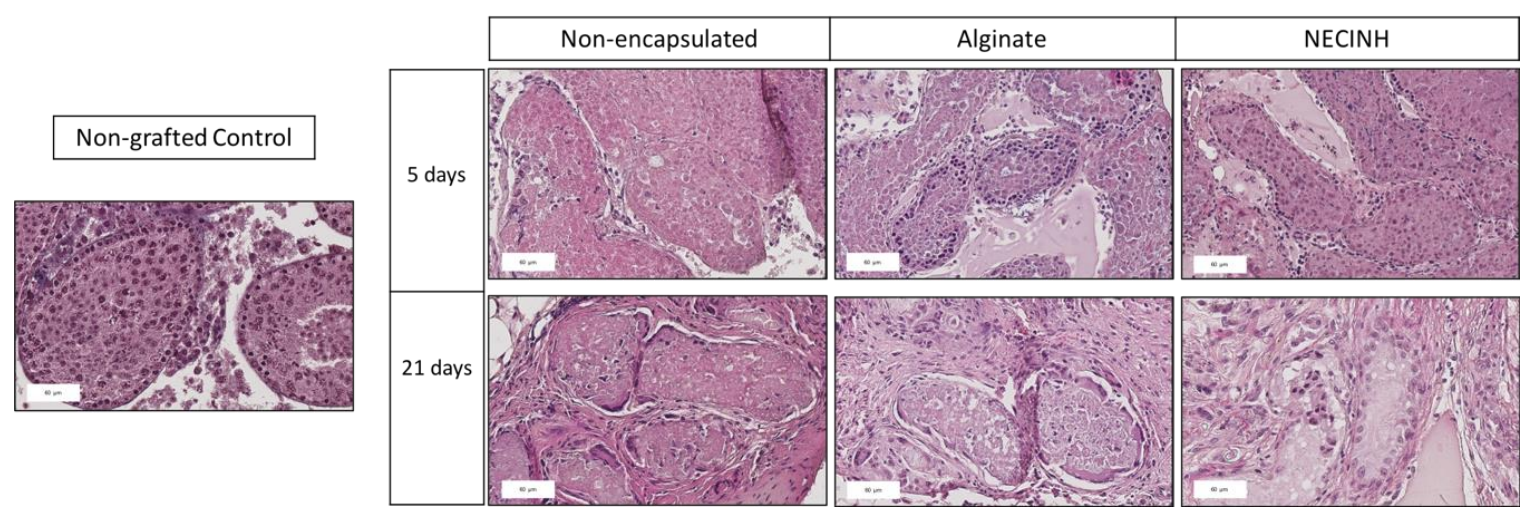

Figure 5. Impact of NECINH-nanoparticles-(NPs) loaded hydrogel on mice testicular tissue after autotransplantation for 5 and 21 days. Hematoxylin-eosin staining was used for the morphological evaluation of seminiferous tubules sections. Scale bar $=60 \mu \mathrm{m}$.

Results for each timing and condition are summarized in Table 2.

Table 2. Impact of NECINH-nanoparticles(NPs)-loaded hydrogel on mice testicular tissue after autotransplantation for 5 and 21 days. Results for tissue integrity are expressed as the mean percentage of STs (seminiferous tubule sections) for each integrity score and condition \pm standard deviation. $n=30$. * indicates $p<0.05$ relative to day 21 Score 1 NECINH-NPs.

\begin{tabular}{|c|c|c|c|}
\hline \multirow[t]{2}{*}{5 Days } & \multicolumn{3}{|c|}{ Integrity Score of STs } \\
\hline & Non-Encapsulated & Alginate & NECINH-NPs \\
\hline Score 1 & $2.7 \% \pm 3 \%$ & $0.35 \% \pm 0 \%$ & $2.58 \% \pm 4 \%$ * \\
\hline Score 2 & $37 \% \pm 27 \%$ & $31.7 \% \pm 15 \%$ & $45.8 \% \pm 18 \%$ \\
\hline Score 3 & $60 \% \pm 26 \%$ & $69.1 \% \pm 13 \%$ & $51.6 \% \pm 18 \%$ \\
\hline \multirow[t]{2}{*}{21 days } & \multicolumn{3}{|c|}{ Integrity score of STs } \\
\hline & Non-encapsulated & Alginate & NECINH-NPs \\
\hline Score 1 & $5 \% \pm 3 \% *$ & $4.1 \% \pm 1.9 \%$ * & $28 \% \pm 15 \%$ \\
\hline Score 2 & $65 \% \pm 14 \%$ & $59 \% \pm 23 \%$ & $56 \% \pm 6 \%$ \\
\hline Score 3 & $29 \% \pm 13 \%$ & $37 \% \pm 24 \%$ & $18 \% \pm 15 \%$ \\
\hline
\end{tabular}

For each of the three groups, we found an improvement in the number of STs classified as intact and satisfactory (Score $1+2$ ) between 5 and 21 days (non-encapsulated tissue: $p=0.02$; Alginate: $p=0.03$; NECINH: $p=0.01$ ).

After 21 days of transplantation, supplementation of the alginate hydrogel with NECINH-NPs was associated with an increased number of intact STs compared to both non-encapsulated tissue $(p=0.007)$ and tissue encapsulated in alginate $(p=0.004)$. An increase of the STs scored as intact was observed between 5 and 21 days only when testicular tissue was encapsulated in NECINH NPs-loaded hydrogels $(p<0.0001)$ (Figure 6). 


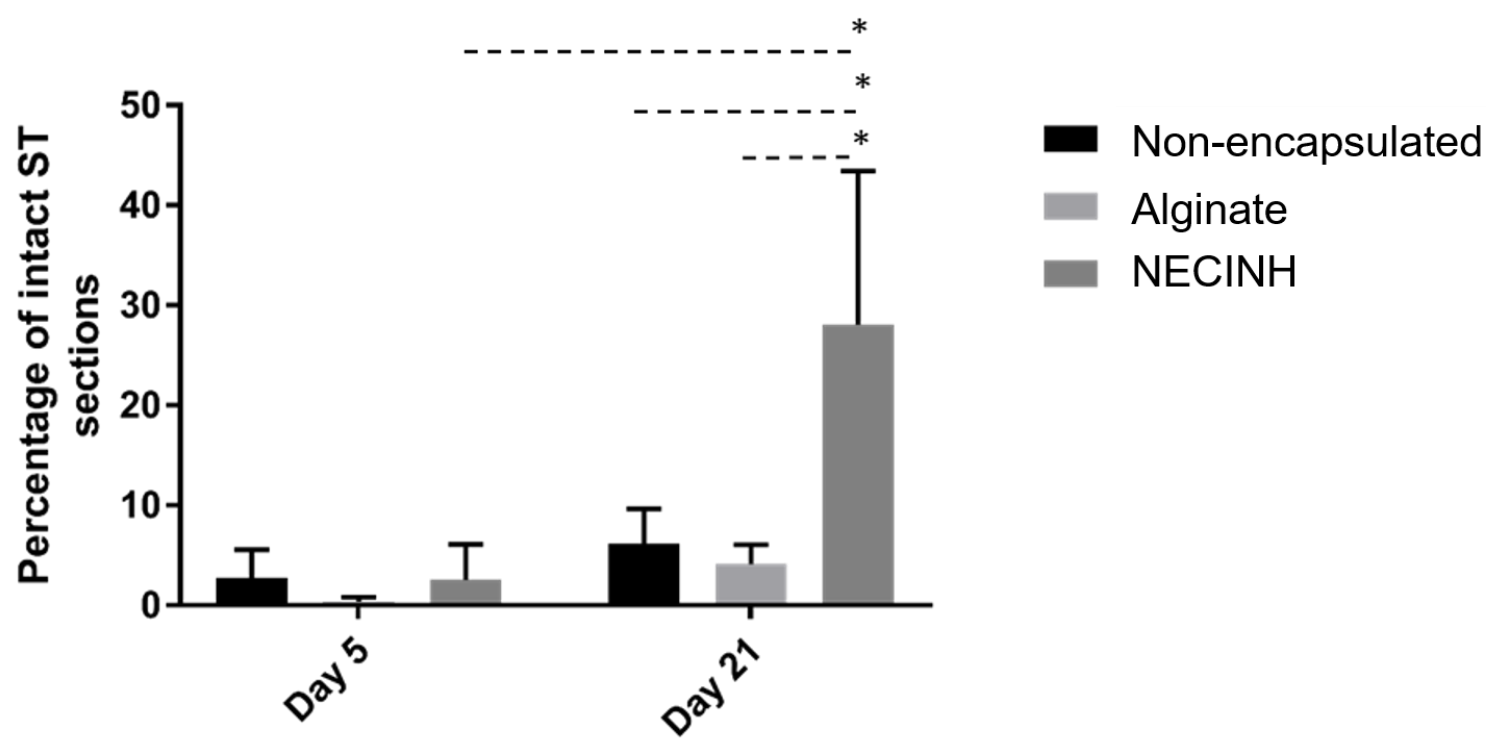

Figure 6. Impact of NECINH-nanoparticles-loaded hydrogel on mice testicular tissue after autotransplantation for 5 and 21 days. Tissue integrity evaluation on hematoxylin-eosin stained slides. The graph shows the percentage of intact (Score 1) STs (seminiferous tubule sections) evaluated at day 5 and day $21 .{ }^{*}$ indicates $p<0.05$ relative to day 21 Score 1 NECINH-NPs.

\subsubsection{Germ Cells' Survival}

Germ cells' survival was analyzed on tissue recovered after 21 days of grafting. Immunohistochemistry (IHC) for PLZF identified spermatogonia that did not enter the differentiating cycle, representing a specific germ cell population with the ability to proceed through mitosis or to provide a more differentiated germ cells. In order to evaluate more differentiated germ cells, such as spermatocytes, we performed IHC for protein boule-like (BOLL). VASA was used as a second marker for both spermatogonia and spermatocytes.

Significantly higher numbers of germ cells survived when the testicular tissue was encapsulated in NECINH NPs-loaded alginate hydrogels. IHC for PLZF, BOLL, and VASA showed a significantly higher number of positive cells/seminiferous tubule sections when tissue encapsulated with NECINH-NPs was compared to both non-encapsulated tissue and tissue encapsulated in alginate, and when the tissue was encapsulated in alginate compared to non-encapsulated tissue (Figures 7 and 8). 


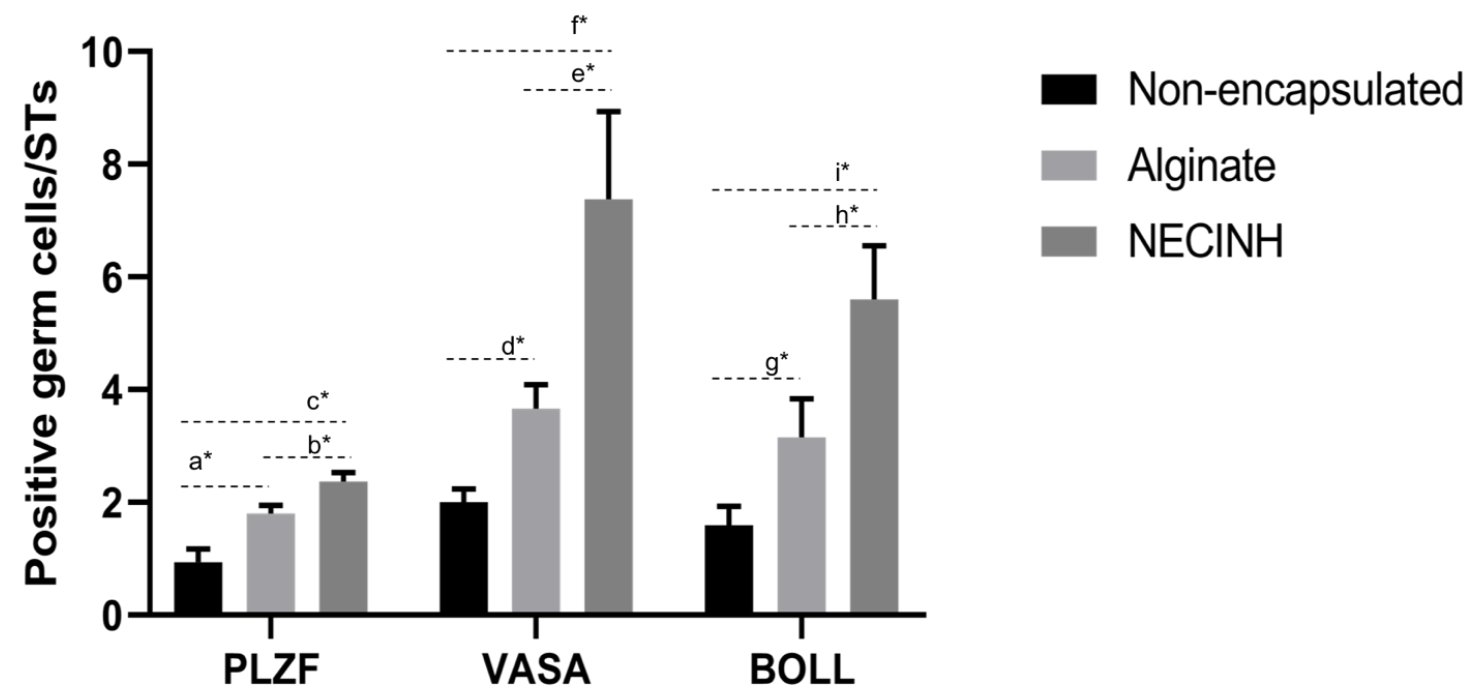

Figure 7. Impact of NECINH-nanoparticles (NPs)-loaded hydrogel on germ cells survival in mice testicular tissue after 21 days of autotransplantation. The number of positive cells/ST section for each germ cell marker (Promyelocytic leukemia zinc finger (PLZF), VASA, and protein boule-like (BOLL)) was statistically significantly higher for NECINH encapsulation compared to both alginate-only and non-encapsulation and for alginate-only encapsulation compared to non-encapsulation. Results are expressed as mean number of positive cells/seminiferous tubule section \pm standard deviation. For PLZF, Non-encapsulated: $0.94 \pm 0.23$; Alginate: $1.80 \pm 0.14$; NECINH $2.37 \pm 0.15$. a: alginate/non-encapsulated tissue $(p<0.0001) ; \mathrm{b}$ : NECINH NPs/non-encapsulated tissue $(p<0.0001)$; c: NECINH NPs/alginate $(p=0.0009)$. For VASA, Non-encapsulated: $2 \pm 0.23$; Alginate: $3.66 \pm 0.43 ;$ NECINH $7.38 \pm 1.56 \mathrm{~d}$ : alginate/non-encapsulated tissue $(p=0.0415)$; e: NECINH-NPs/ alginate ( $p=0.0001)$; f: NECINH-NPs/non-encapsulated tissue $(p<0.0001)$. For BOLL, Non-encapsulated: $1.60 \pm 0.34$; Alginate: $3.16 \pm 0.68 ; \mathrm{NECINH} 5.60 \pm 0.95$. g: alginate/non-encapsulated tissue ( $p=0.00111)$; h: NECINH-NPs/alginate $(p=0.0004)$; i: NECINH-NPs/non-encapsulated tissue $(p$ $<0.0001)$. ${ }^{*}$ statistical significant results $(p<0.05)$. 

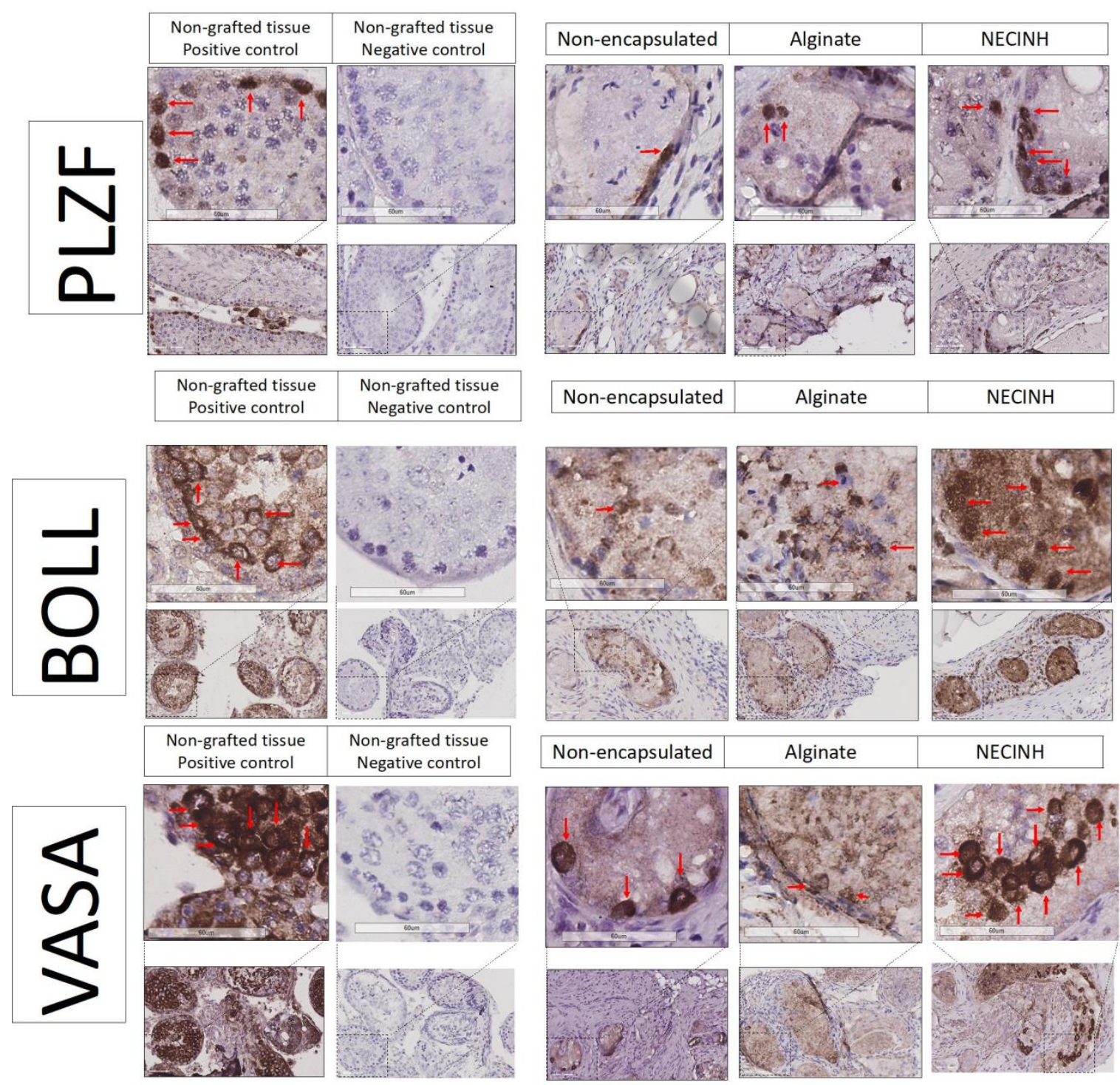

Figure 8. Impact of NECINH-NPs on germ cells survival in mice testicular tissue auto-transplanted for 21 days. Images show $40 \mathrm{X}$ magnification of IHC for PLZF, BOLL, and VASA. Positive cells are highlighted by red arrows.

\subsubsection{Intratubular Apoptosis}

Active caspase- 3 was used as the end-marker of the caspase-dependent apoptotic cell death pathway to identify cells going through apoptosis.

No statistical difference between the three conditions was found regarding the number of active caspase-3 positive cells/STs after 5 or after 21 days (Table 3). see Figure S2. 
Table 3. Impact of NECINH-nanoparticles(NPs)-loaded hydrogel on apoptosis (active caspase 3-positive cells) and membrane lipid peroxidation (Malondialdehyde (MDA)-positive cells). After 5 days of transplantation, no effect on apoptosis was observed. MDA+ cells were reduced in alginate and NECINH groups. After 21 days of transplantation, no effect on apoptosis or lipid peroxidation was observed. Results are expressed as a mean number of positive cells/seminiferous tubule section \pm standard deviation. ${ }^{*}$ indicates $p<0.05$ relative to day 5 non-encapsulated.

\begin{tabular}{cccc}
\hline $\mathbf{5}$ days & Non-Encapsulated & Alginate & NECINH-NPs \\
\hline Active-caspase 3 & $2.7 \pm 1$ & $2.7 \pm 0.7$ & $1.9 \pm 0.5$ \\
MDA & $1.3 \pm 0.9$ & $0.09 \pm 0.09 *$ & $0.2 \pm 0.2^{*}$ \\
\hline 21 days & Non-Encapsulated & Alginate & NECINH-NPs \\
\hline Active-caspase 3 & $1.3 \pm 0.5$ & $1.4 \pm 0.5$ & $0.9 \pm 0.5$ \\
MDA & $0.9 \pm 0.2$ & $1.4 \pm 1.5$ & $0.6 \pm 0.2$ \\
\hline
\end{tabular}

\subsubsection{Oxidative Stress Evaluation Using Malondialdehyde (MDA)}

As exposure to oxidative stress induces the peroxidation of cell membranes' polyunsaturated fatty acids, cells accumulating MDA as an end-product of lipid oxidation were identified to assess the protective effect of NECINH-NPs against oxidative stress in tissue grafts.

Five days after transplantation, significantly more MDA-positive cells were observed for non-encapsulated tissue compared to both tissue encapsulated in alginate $(p=0.0073)$ and alginate with NECINH-NPs ( $p=0.0132$ ) (Table 3, Figure 9). After 21 days of grafting, no difference between the three conditions was found (Table 3, Figure 9).
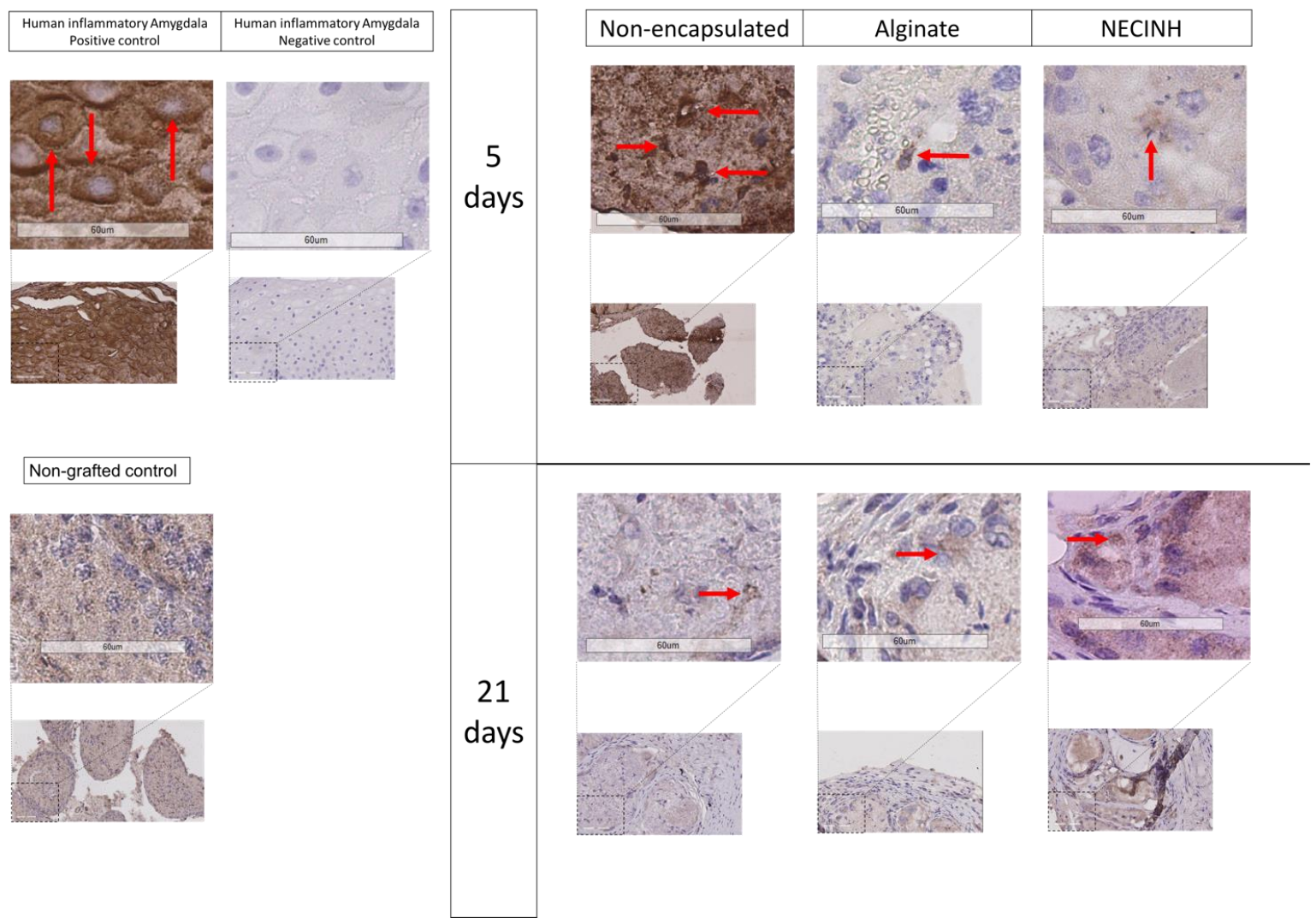

Figure 9. Impact of NECINH nanoparticles (NPs)-loaded hydrogel on lipid peroxidation in mice testicular tissue after autotransplantation for 5 and 21 days. Malondialdehyde (MDA)-positive cells were reduced on day 5 when encapsulation in alginate was performed, regardless of NPs supplementation. Positive cells are highlighted by red arrows. 


\section{Discussion}

The results of our study represented a significant step towards the development of optimal transplantation procedures that are awaited before considering autotransplantation of cryobanked ITT from prepubertal boys aiming at future fertility restoration.

Indeed, encapsulation in a 1\% alginate matrix with supplementation of NPs allowing localized, controlled, and sustained delivery of necrosis inhibitor improved spermatogonial and germ cells' survival and tissue integrity in mouse testicular tissue avascular autografts, a model also previously used to assess human ITT xenografts where an important spermatogonial loss was observed [17,33,34].

All strategies that are intended to restore a patient's fertility using his own frozen-thawed ITT, using in vivo or in vitro approaches rely on the presence of spermatogonia as precursors of spermatozoa [4]. Furthermore, in both mouse and human testicles, spermatogonial stem cells have been quantified as scarce [27,35], and their number seems to be further reduced in patients affected by diseases, such as sickle cell anemia and leukemia [2].

Hence, as far as it concerns cryostored ITT, increasing spermatogonial survival represents a challenge, whatever the technique that could offer an option for fertility restoration [36].

The objective of this study was to evaluate a new approach to increase the transplantation efficiency by reducing oxidative stress based on well-known antioxidant properties of alginate [37] and by diminishing tissue necrosis with a necrosis inhibitor. To evaluate the impact of our combinational approach on hypoxia-reoxygenation events in grafts, we decided to evaluate tissue integrity after 5 days of transplantation to study the effect of the hypoxia that precedes the revascularization, and after 21 days to investigate the effect of revascularization and reoxygenation.

Previous experiments involving mice testicular tissue autotransplantation showed that NPs delivering VEGF improved short-term vascularization without exerting any effect on spermatogonia survival and that alginate itself, regardless of the addition of VEGF-NPs, increased the survival of spermatogonia [30].

We here showed that the incorporation of testicular tissue in NECINH-NPs-loaded alginate hydrogel significantly improved both tissue integrity and spermatogonial survival when compared to encapsulation in alginate alone, progressing towards better chances of achieving successful fertility restoration with ITT transplantation.

No previous reports are available concerning the delivery of NECINH with NPs, and our results provided insights into a new tool that might be applied to fertility preservation techniques. Nanomedicines loaded with NECINH were successfully prepared, and the obtained, sustained, and controlled release profile was ideal as the first-week post-transplantation was shown to be critical for graft development [21].

Validating the ex vivo model of hypoxia-induced toxicity provided an effective and accessible tool to explore the impact of hypoxia on testicular tissue. This experimental model was used to evaluate the influence of NECINH-NPs-supplemented hydrogel on tissue and cell viability in vitro. The absence of NECINH-NPs toxicity on mice testicular tissue was observed based on LDH quantification. These results were supported by a significant increase of spermatogonia surviving after in vivo transplantation compared to alginate alone as a valuable achievement in the field of fertility preservation. As the mouse spermatogenic cycle lasts for 35 days [38], we expected partial germ cell differentiation in the tissue recovered after 21 days of transplantation, and we also evaluated the presence of spermatocytes, a population of germ cells more differentiated than spermatogonia [39]. The increased numbers of spermatocytes demonstrated by immunostaining for both BOLL and VASA represented a further confirmation of the positive effect of NECINH-NPs on testicular tissue. Besides the enhanced survival of undifferentiated spermatogonia (PLZF-positive cells), we confirmed their short-term ability to enter the differentiation pathway and thus the potential to deliver more differentiated germ cells with NECINH-NPs.

As a reduction in MDA-positive cells/seminiferous tubule was observed 5 days after transplantation, regardless of supplementation with NECINH-NPs, the reduction in membrane 
lipid peroxidation and thus reduced oxidative stress was most likely due to the antioxidant properties of alginate [40].

Immunostaining for active caspase- 3 on tissue recovered after 5 and 21 days of transplantation did not point to any effect of NECINH-NPs supplementation on caspase-dependent apoptosis. The few previous studies investigating possible effects of NECINH NecroX-5 ${ }^{\mathrm{TM}}$ on apoptosis are controversial. Indeed, NecroX-5 $5^{\mathrm{TM}}$ administration was shown to interfere with apoptosis, causing inhibition of caspase-3 cleavage and downregulation of Bcl-2 protein [41], as well as a reduction of DNA fragmentation evidenced by terminal deoxynucleotidyl transferase dUTP nick end labeling (TUNEL) [42,43]. By contrast, our observations were in agreement with those of Kim et al. [31], who did not see such effect with the administration of a molecule acting on caspase-dependent apoptosis on rat hepatocytes exposed in vitro to tertiary-butyl-hydroperoxide (t-BHP)-induced cellular injury. In addition, besides the anti-necrosis properties of NecroX-5 ${ }^{\mathrm{TM}}$, anti-inflammatory properties previously described [44], as well as a recently reported effect on macrophage response [45], could have contributed to the results we obtained. A deeper understanding of the pathways involved in the NecroX-5 $5^{\mathrm{TM}}$ mode of action, especially when delivered in such a localized and sustained fashion, would be useful for further applications. Increasing NECINH concentration in the encapsulation matrix beyond the threshold of $10 \mu \mathrm{M}$ might further improve tissue survival, as a dose-dependent effect was documented for myoblasts exposed in vitro to tert-butyl-hydroperoxide [31], and the half-maximal inhibitory concentration (IC50) tested in vitro was beyond $96 \mu \mathrm{M}$ [46].

Evaluating transplantation results over a period longer than 21 days (the period needed for neovessels stabilization) [23] might also provide more information concerning germ cell differentiation and functionality in future experiments. However, animal tissue was used in these series of experiments to allow comparison of several groups of treatment in vitro and in vivo using a completely new strategy for the transplantation procedure and thus avoid unethical use of scarce human prepubertal tissue available for research purposes.

Before considering any clinical application of ITT transplantation, several issues concerning the safety of the procedure should still be addressed besides the risk linked to potential contamination of the tissue with cancer cells. Indeed, the possibility of epigenetic modifications that could be induced by the transplantation and tissue encapsulation environment should be evaluated.

With regard to the administration to humans, in spite of the encouraging results obtained in experiments carried out both in vitro and in vivo, the efficacy and safety of NPs should further be addressed [47]. In order to be effective, NPs should allow localized interaction of the drug with the target tissue and cells, thus avoid reticuloendothelial system sequestration and phagocytosis by macrophages and at the same time increase stability and solubility of the encapsulated molecules [48]. Pharmacology interventions aimed at reaching these objectives are supposed to take into consideration possible adverse effects, such as potential toxicity of the products of degradation of the polymer used for encapsulation and the accumulation and diffusion of NPs to the central nervous system after passing the blood-brain barrier [49]. Three-dimensional images of nanoparticles obtained through techniques like scanning electron microscopy (SEM) [50] could help to provide further insights on factors that could interfere with drug delivery.

Moreover, while alginate [51] and PLGA nanomedicines [52] have been authorized by the food and drug administration for use in humans, this does not apply to molecules belonging to the NecroX family yet.

\section{Materials and Methods}

\subsection{NECINH Encapsulation in PLGA:PLGA-PEG Nanoparticles}

PLAG-PEG NPs containing NECINH were produced by single emulsion [53] and characterized in terms of morphology, zeta potential, size, and encapsulation efficiency. 
Thirty-five milligrams of PLGA (Resomer ${ }^{\circledR}$ RG 502H, Sigma-Aldrich-719897, Darmstadt, Germany) and $15 \mathrm{mg}$ of PLGA-PEG (Resomer ${ }^{\circledR}$ RGP d 50155, Boehringer Ingelheim, Ingelheim, Germany) were dissolved in $1 \mathrm{~mL}$ dichloromethane $\left(\mathrm{CH}_{2} \mathrm{CL}_{2}\right)$. Two hundred fifty micrograms of NECINH NecroX-5 ${ }^{\mathrm{TM}}$ in acetone and $2 \mathrm{~mL}$ of $1 \%$ poly (vinyl alcohol) (PVA) (88\% Hydrolyzed, MW 22000-30000, Across Organic 396765000) were added to the solution. An emulsion was obtained by sonication (70W, $15 \mathrm{~s})$ that was then added drop by drop onto $100 \mathrm{~mL}$ of $0.3 \%$ PVA solution and stirred (room temperature, $550 \mathrm{rpm}$ ) to allow the solvent to evaporate. Hardened NPs were then centrifuged at 22,000 $\mathrm{g}$ for $30 \mathrm{~min}$ at $4{ }^{\circ} \mathrm{C}$ and washed 3 times in water. NPs were then resuspended in $1 \mathrm{~mL}$ Milli-Q water (stock solution).

\subsubsection{Physico-Chemical Characterization of NecroX-5 Nanoparticles}

Size, zeta-potential, and PDI (polydispersity index) of NecroX-5 NPs were measured using a Zetasizer (Malvern Panalytical, Malvern, UK). Samples were diluted 1/100 (v/v) in Milli-Q water, and the encapsulation efficiency of NecroX- 5 was calculated by using the following formula:

$$
\text { Encapsulation Efficiency }=\frac{\text { NecroX }-5 \text { introduced in the formulation }- \text { encapsulated NecroX }-5}{\text { NecroX }-5 \text { introduced in the formulation }} * 100
$$

Necrox- 5 concentration was measured by fluorimetry (excitation wave $\lambda=330 \mathrm{~nm}$, emission wave $\lambda=460 \mathrm{~nm})$.

\subsubsection{NecroX-5 In Vitro Release}

NecroX-5 NPs were dispersed in $45 \mu \mathrm{L}$ of $1 \%$ alginate (SLM100, FMC BioPolymers, NovaMatrix ${ }^{\mathrm{TM}}$, Sandvika, Norway) solution in 3-(n-morpholino)propanesulfonic acid, 4-morpholinepropanesulfonic acid (MOPS buffer) (M3183; Sigma-Aldrich, Darmstadt, Germany), prepared as previously described [30], and $5 \mu \mathrm{L}$ of $\mathrm{CaCl}_{2}$ (50 mM solution in MOPS) was added to initiate gelation.

Hydrogels were placed in 96-well plates, covered with $250 \mu \mathrm{L}$ of $40 \mathrm{mM} \mathrm{CaCl}_{2} \mathrm{PBS}$, and incubated at $37^{\circ} \mathrm{C}$. Release media were collected at different timings ( $4 \mathrm{~h}$, and $1,2,4,10,15,21$ days). Samples were centrifuged, and NecroX-5 was quantified by fluorimetry after a 2-times dilution in PBS. Results were expressed as the percentage of released NecroX- 5 compared to the total amount of NecroX- 5 added in the hydrogel.

\subsection{Ethical Approval and Animal Care}

All experiments involving animals were approved by the Ethics Review Board and the Committee on Animal Research of UCLouvain (project 2018/UCL/MD/20, approval date: 22 June 2018) according to the laws currently in force in Belgium (Royal Decree on the Protection of Experimental Animals 29th Mai, 2013). NMRI (Naval Medical Research Institute) mice were purchased directly from the animal facility of UCLouvain and were kept in cages with usual night/day cycle with water and food available ad libitum and received the animal care in compliance with university guidelines. Animals were randomly assigned to experimental or control groups (5 mice per group). All experimental surgical procedures were carried out inside the university animal housing facility (Linné building, UCLouvain, Woluwe Saint-Lambert, Belgium), and no adverse reaction was documented.

\subsection{Impact of Nanoparticles Containing Necrosis Inhibitor on Tissue Necrosis In Vitro}

To validate that incubation of testicular tissue fragments in hypoxia-induced cytolysis, lactate dehydrogenase (LDH) levels in the supernatant of tissues kept for 5 days in hypoxia (incubator with $1 \% \mathrm{O}_{2}$ ) (INVIVO2400 hypoxic chamber, Ruskinn Technology, Ltd., Bridgend UK) or in normoxia (21\% $\mathrm{O}_{2}$ ) were first compared (Figure S1).

Testicles were collected after bilateral orchidectomy, as previously described, from 3 NMRI mice aged between 4 and 5 weeks and weighted 28-32 $\mathrm{g}$. The testicular tissue obtained from both testicles 
was cut in small fragments $\left( \pm 1 \mathrm{~mm}^{3}\right)$. One percent of alginate hydrogel was used for tissue embedding to facilitate manipulations [30]. Tissue fragments were placed in a sterile petri dish containing $45 \mu \mathrm{L}$ of $1 \%$ alginate solution and $10 \mu \mathrm{M}$ of NECINH-NPs with the further addition of $5 \mu \mathrm{L}$ of $\mathrm{CaCl}_{2}$ to initiate the gelation. Non-encapsulated tissue fragments and fragments encapsulated in alginate alone were used as negative controls. Four fragments per mouse ( 2 of each testis) were cultured for each of the three groups. All fragments were placed on Millicell ${ }^{\circledR}$ (Millipore, cell culture inserts, $12 \mathrm{~mm} / 0.4 \mu \mathrm{m}$, Darmstadt, Germany) on 24-well plates keeping an air-liquid interface [54]. Three hundred microliters of culture medium composed of $\alpha$-MEM ( $\alpha$-minimum essential medium, without phenol Gibco ${ }^{\mathrm{TM}}$, 32561029, Waltham, MA, USA), Penicillin/Streptomycin (Thermo-Fisher ${ }^{\text {TM }}$, 15070063, Waltham, MA, USA), and FBS (fetal bovine serum) (ThermoFisher ${ }^{\mathrm{TM}}$, 10500056, Waltham, MA, USA) were added per well. Samples were kept in a hypoxia incubator (INVIVO2400 hypoxic chamber, Ruskinn Technology, Ltd., Bridgend UK) set at $1 \%$ of $\mathrm{O}_{2}$ for up to 21 days. One testicular tissue fragment per mouse was collected after 5 days and 3 after 21 days for histological and immunohistochemical analyses (see Section 4.5). One testicular fragment per mouse was also fixed immediately after sampling in $\mathrm{mDF}$ (modified Davidson's fluid) as a positive control. Culture media were collected after 4, 8, $24 \mathrm{~h}$, and then every $48-72 \mathrm{~h}$ up to 21 days and stored at $-20{ }^{\circ} \mathrm{C}$ until further analysis. Cytotoxicity was evaluated by measuring LDH concentration according to the supplier instructions (CytoTOX-ONE kit (PromegaTM G7890, Leiden, Netherlands)).

\subsection{Impact of Nanoparticles Containing Necrosis Inhibitor In Vivo on Auto-Transplanted Testicular Tissue}

NMRI mice $(n=30)$ were anesthetized by an intraperitoneal injection of medetomidine $(1 \mathrm{mg} / \mathrm{kg})$ (Domitor, Pfizer, Cambridge, MA, USA) and ketamine ( $75 \mathrm{mg} / \mathrm{kg}$ ) (Anesketin, Eurovet, Heusden-Zolder, Belgium). Analgesia was provided by intraperitoneal injection of buprenorphine $(0.1 \mathrm{mg} / \mathrm{kg})$ (Temgesic, Schering Plough, Kenilworth, NJ, USA). Intraperitoneal injection of atipamezole (1 mg/kg) (Antisedan, Pfizer, Cambridge, MA, USA) was used to reverse anesthesia.

After bilateral orchidectomy, one $\pm 1 \mathrm{~mm}^{3}$ fragment of autologous testicular tissue was grafted into the scrotum, as previously described [33], without the creation of an artificial vascular anastomosis. Fragments were encapsulated, as described in Section 4.3 Fragments encapsulated in NECINH NPs-loaded hydrogels were compared to controls (non-encapsulated and encapsulated in alginate alone) ( $n=5$ /group). Mice were euthanized by cervical dislocation after 5 or 21 days. Grafts were recovered and fixed in $\mathrm{mDF}$, embedded in paraffin, and cut into $5 \mu \mathrm{m}$-thick serial sections that were placed per pair on Superfrost Plus slides.

\subsection{Histology and Immunohistochemistry Analyses}

For immunohistochemistry, tissue sections were deparaffinized according to common protocols. To block endogenous peroxidase activity, slides were incubated for $30 \mathrm{~min}$ at room temperature (RT) in $0.3 \% \mathrm{H}_{2} \mathrm{O}_{2}$. After washing in distilled water, slides were immersed in citrate buffer for $60 \mathrm{~min}$ at $98{ }^{\circ} \mathrm{C}$ for antigen retrieval and incubated for $30 \mathrm{~min}$ at RT with $10 \%$ normal goat serum (NGS, Invitrogen, Merelbeke, Belgium) and 1\% bovine serum albumin (BSA) (Invitrogen, Merelbeke, Belgium) to block non-specific binding sites. Primary antibodies were added to the slides according to the manufacturer's suggested concentrations and incubated at $4{ }^{\circ} \mathrm{C}$. We used anti-promyelocytic leukemia zinc finger (PLZF) (rabbit anti-PLZF antibody, 1/400, Sigma-Aldrich, HPA001499, St. Louis, MO, USA) as a marker of undifferentiated spermatogonia [55]; VASA (rabbit anti-VASA antibody, 1/2000, ab13840, Abcam, Cambridge, UK) as a marker of spermatogonia, spermatocytes, and rounds spermatids [56]; BOLL (rabbit anti-BOLL antibody, 1/1600, Sigma-Aldrich, HPA 0488-13, St. Louis, MO, USA) as a marker of spermatocytes and round spermatids [57]; anti-active caspase 3 (rabbit anti active caspase-3, 1/200, Promega G7481, Leiden, Netherlands) to identify cells expressing cleaved caspase 3 [58]; and anti-malondialdehyde (MDA) (rabbit anti-MDA antibody, 1/1000, Ab6463, Abcam, Cambridge, UK) to identify cells presenting evidence of lipid peroxidation as a sign of oxidative stress [59,60]. A secondary anti-rabbit antibody (Envision+ system-labeled polymer-horseradish peroxidase (HRP); DAKO, K4003) 
was added to the sections and incubated for $60 \mathrm{~min}$ at RT. Diaminobenzidine (DAKO K3468) was used as chromogen, and Mayer's hematoxylin was employed to counterstain nuclei. After washing with tap water, slides were dehydrated with serial baths in methanol and toluene, and Entellan mounting medium (Sigma-Aldrich, St. Louis, MO, USA) was used with coverslips to seal the slides. All tissues were analyzed on digital images captured with a Leica SCN400 slide scanner (Leica Biosystems, WETZLAP, Nußloch Germany).

Results were expressed as the mean number of positive cells per seminiferous tubule (ST) section. For the ST integrity score, a slide every $50 \mu \mathrm{m}$ was stained with hematoxylin-eosin (HE). We used the scoring criteria previously described [30] to assess ST integrity (Figure S3).

\subsection{Statistical Analysis}

Statistical analyses were performed using GraphPad Prism (GraphPad Software, La Jolla, CA, USA).

Shapiro-Wilk test was applied to validate the normal distribution of data, and one-way ANOVA with Tukey posthoc test was used to compare the means of three groups. Results are expressed as mean $+/$ - standard deviation and were considered significant if $p<0.05$.

\section{Conclusion}

Our results confirm that our strategy has a relevant potential for further studies involving human tissue. The testicular tissue transplantation experiments with alginate hydrogel and VEGF NPs [30] and here with NECINH-NPs represent a paradigm for future applications of tissue engineering procedures applied to fertility preservation and other fields of regenerative medicine.

Supplementary Materials: Supplementary materials can be found at http:/www.mdpi.com/1422-0067/20/23/ 5833/s1. Figure S1. Validation experience. Figure S2. Impact of NECINH nanoparticles(NPs) loaded hydrogel on apoptosis in mice testicular tissue after auto-transplantation for 5 and 21 days. Figure S3. Seminiferous tubules sections scoring criteria.

Author Contributions: F.D.V. performed the experiments, analyzed the results, and wrote the manuscript. M.V. helped to perform the experiments and participated in the discussion. B.U. helped to develop the nanoparticles. J.P. participated in the project design and contributed to the analysis of the results. A.d.R. participated in the project design and reviewed the manuscript. C.W. was responsible for the project concept, interpretation of results, critical discussion, and reviewed the manuscript.

Funding: The studies conducted were supported by grants from the Fondation contre le cancer (2016-141 FAF-C/2016/745) and the Fondation Salus Sanguinis. Anne des Rieux is a research associate from the FRS-FNRS (Fonds de la Recherche Scientifique, Belgique) and is a recipient of subsidies from the Fonds Spéciaux de Recherche Scientifique (FSR, UCL).

Acknowledgments: We would like to thank IREC's Imaging and Cytometry Technology Platforms - UCL (Catholic University of Louvain) for their technical support for tissue analysis. This research has benefitted from the statistical consult with Statistical Methodology and Computing Service, the technological platform at UCL-SMCS/IMMAQ, UCL.

Conflicts of Interest: The authors declare no conflict of interest.

\section{References}

1. Trama, A.; Botta, L.; Foschi, R.; Ferrari, A.; Stiller, C.; Desandes, E.; Maule, M.M.; Merletti, F.; Gatta, G.; Group, E.-W. Survival of European adolescents and young adults diagnosed with cancer in 2000-07: Population-based data from EUROCARE-5. Lancet Oncol. 2016, 17, 896-906. [CrossRef]

2. Stukenborg, J.B.; Alves-Lopes, J.P.; Kurek, M.; Albalushi, H.; Reda, A.; Keros, V.; Tohonen, V.; Bjarnason, R.; Romerius, P.; Sundin, M.; et al. Spermatogonial quantity in human prepubertal testicular tissue collected for fertility preservation prior to potentially sterilizing therapy. Hum. Reprod. 2018, 33, 1677-1683. [CrossRef] [PubMed]

3. Wyns, C.; Curaba, M.; Vanabelle, B.; Van Langendonckt, A.; Donnez, J. Options for fertility preservation in prepubertal boys. Hum. Reprod. Update 2010, 16, 312-328. [CrossRef] [PubMed] 
4. Clermont, Y. Kinetics of spermatogenesis in mammals: Seminiferous epithelium cycle and spermatogonial renewal. Physiol. Rev. 1972, 52, 198-236. [CrossRef]

5. Wyns, C.; Curaba, M.; Petit, S.; Vanabelle, B.; Laurent, P.; Wese, J.F.; Donnez, J. Management of fertility preservation in prepubertal patients: 5 years' experience at the Catholic University of Louvain. Hum. Reprod. 2011, 26, 737-747. [CrossRef]

6. $\quad$ Picton, H.M.; Wyns, C.; Anderson, R.A.; Goossens, E.; Jahnukainen, K.; Kliesch, S.; Mitchell, R.T.; Pennings, G.; Rives, N.; Tournaye, H.; et al. A European perspective on testicular tissue cryopreservation for fertility preservation in prepubertal and adolescent boys. Hum. Reprod. 2015, 30, 2463-2475. [CrossRef]

7. Corkum, K.S.; Lautz, T.B.; Johnson, E.K.; Reimann, M.B.; Walz, A.L.; Lockart, B.A.; Brannigan, R.E.; ValliPulaski, H.; Orwig, K.E.; Rowell, E.E. Testicular wedge biopsy for fertility preservation in children at significant risk for azoospermia after gonadotoxic therapy. J. Pediatr. Surg. 2019, 54, 1901-1905. [CrossRef]

8. Wyns, C.; Collienne, C.; Shenfield, F.; Robert, A.; Laurent, P.; Roegiers, L.; Brichard, B. Fertility preservation in the male pediatric population: Factors influencing the decision of parents and children. Hum. Reprod. 2015, 30, 2022-2030. [CrossRef]

9. Honaramooz, A.; Snedaker, A.; Boiani, M.; Scholer, H.; Dobrinski, I.; Schlatt, S. Sperm from neonatal mammalian testes grafted in mice. Nature 2002, 418, 778-781. [CrossRef]

10. Brinster, R.L.; Zimmermann, J.W. Spermatogenesis following male germ-cell transplantation. Proc. Natl. Acad. Sci. USA 1994, 91, 11298-11302. [CrossRef]

11. de Michele, F.; Vermeulen, M.; Wyns, C. Fertility restoration with spermatogonial stem cells. Curr. Opin. Endocrinol. Diabetes Obes. 2017, 24, 424-431. [CrossRef] [PubMed]

12. Vermeulen, M.; Del Vento, F.; de Michele, F.; Poels, J.; Wyns, C. Development of a Cytocompatible Scaffold from Pig Immature Testicular Tissue Allowing Human Sertoli Cell Attachment, Proliferation and Functionality. Int. J. Mol. Sci. 2018, 19. [CrossRef] [PubMed]

13. Pendergraft, S.S.; Sadri-Ardekani, H.; Atala, A.; Bishop, C.E. Three-dimensional testicular organoid: A novel tool for the study of human spermatogenesis and gonadotoxicity in vitro. Biol. Reprod. 2017, 96, 720-732. [CrossRef] [PubMed]

14. Sakib, S.; Yu, Y.; Voigt, A.; Ungrin, M.; Dobrinski, I. Generation of Porcine Testicular Organoids with Testis Specific Architecture using Microwell Culture. J. Vis. Exp. 2019. [CrossRef] [PubMed]

15. Del Vento, F.; Vermeulen, M.; de Michele, F.; Giudice, M.G.; Poels, J.; des Rieux, A.; Wyns, C. Tissue Engineering to Improve Immature Testicular Tissue and Cell Transplantation Outcomes: One Step Closer to Fertility Restoration for Prepubertal Boys Exposed to Gonadotoxic Treatments. Int. J. Mol. Sci. 2018, 19. [CrossRef] [PubMed]

16. Fayomi, A.P.; Peters, K.; Sukhwani, M.; Valli-Pulaski, H.; Shetty, G.; Meistrich, M.L.; Houser, L.; Robertson, N.; Roberts, V.; Ramsey, C.; et al. Autologous grafting of cryopreserved prepubertal rhesus testis produces sperm and offspring. Science 2019, 363, 1314-1319. [CrossRef]

17. Wyns, C.; Van Langendonckt, A.; Wese, F.X.; Donnez, J.; Curaba, M. Long-term spermatogonial survival in cryopreserved and xenografted immature human testicular tissue. Hum. Reprod. 2008, 23, 2402-2414. [CrossRef]

18. Goossens, E.; Geens, M.; De Block, G.; Tournaye, H. Spermatogonial survival in long-term human prepubertal xenografts. Fertil. Steril. 2008, 90, 2019-2022. [CrossRef]

19. Sato, Y.; Nozawa, S.; Yoshiike, M.; Arai, M.; Sasaki, C.; Iwamoto, T. Xenografting of testicular tissue from an infant human donor results in accelerated testicular maturation. Hum. Reprod. 2010, 25, 1113-1122. [CrossRef]

20. Van Saen, D.; Goossens, E.; Haentjens, P.; Baert, Y.; Tournaye, H. Exogenous administration of recombinant human FSH does not improve germ cell survival in human prepubertal xenografts. Reprod. Biomed. Online 2013, 26, 286-298. [CrossRef]

21. Poels, J.; Abou-Ghannam, G.; Herman, S.; Van Langendonckt, A.; Wese, F.X.; Wyns, C. In Search of Better Spermatogonial Preservation by Supplementation of Cryopreserved Human Immature Testicular Tissue Xenografts with N-acetylcysteine and Testosterone. Front. Surg. 2014, 1, 47. [CrossRef] [PubMed]

22. Ntemou, E.; Kadam, P.; Van Laere, S.; Van Saen, D.; Vicini, E.; Goossens, E. Effect of recombinant human vascular endothelial growth factor on testis tissue xenotransplants from prepubertal boys: A three-case study. Reprod. Biomed. Online 2019, 39, 119-133. [CrossRef] [PubMed] 
23. Van Eyck, A.S.; Jordan, B.F.; Gallez, B.; Heilier, J.F.; Van Langendonckt, A.; Donnez, J. Electron paramagnetic resonance as a tool to evaluate human ovarian tissue reoxygenation after xenografting. Fertil. Steril. 2009, 92, 374-381. [CrossRef] [PubMed]

24. Schlatt, S.; Westernstroer, B.; Gassei, K.; Ehmcke, J. Donor-host involvement in immature rat testis xenografting into nude mouse hosts. Biol. Reprod. 2010, 82, 888-895. [CrossRef]

25. Watkins, M.T.; Haudenschild, C.C.; al-Badawi, H.; Velazquez, F.R.; Larson, D.M. Immediate responses of endothelial cells to hypoxia and reoxygenation: An in vitro model of cellular dysfunction. Am. J. Physiol. 1995, 268, H749-H758. [CrossRef]

26. Li, C.; Jackson, R.M. Reactive species mechanisms of cellular hypoxia-reoxygenation injury. Am. J. Physiol. Cell Physiol. 2002, 282, C227-C241. [CrossRef]

27. Tegelenbosch, R.A.; de Rooij, D.G. A quantitative study of spermatogonial multiplication and stem cell renewal in the C3H/101 F1 hybrid mouse. Mutat. Res. 1993, 290, 193-200. [CrossRef]

28. Vermeulen, M.; Poels, J.; de Michele, F.; des Rieux, A.; Wyns, C. Restoring Fertility with Cryopreserved Prepubertal Testicular Tissue: Perspectives with Hydrogel Encapsulation, Nanotechnology, and Bioengineered Scaffolds. Ann. Biomed. Eng. 2017. [CrossRef]

29. Gaspar, D.; Peixoto, R.; De Pieri, A.; Striegl, B.; Zeugolis, D.I.; Raghunath, M. Local pharmacological induction of angiogenesis: Drugs for cells and cells as drugs. Adv. Drug Deliv. Rev. 2019. [CrossRef]

30. Poels, J.; Abou-Ghannam, G.; Decamps, A.; Leyman, M.; Rieux, A.D.; Wyns, C. Transplantation of testicular tissue in alginate hydrogel loaded with VEGF nanoparticles improves spermatogonial recovery. J. Control. Release 2016, 234, 79-89. [CrossRef]

31. Kim, H.J.; Koo, S.Y.; Ahn, B.H.; Park, O.; Park, D.H.; Seo, D.O.; Won, J.H.; Yim, H.J.; Kwak, H.S.; Park, H.S.; et al. NecroX as a novel class of mitochondrial reactive oxygen species and $\mathrm{ONOO}(-)$ scavenger. Arch. Pharm. Res. 2010, 33, 1813-1823. [CrossRef] [PubMed]

32. Thu, V.T.; Kim, H.K.; Long le, T.; Nyamaa, B.; Song, I.S.; Thuy, T.T.; Huy, N.Q.; Marquez, J.; Kim, S.H.; Kim, N.; et al. NecroX-5 protects mitochondrial oxidative phosphorylation capacity and preserves PGC1alpha expression levels during hypoxia/reoxygenation injury. Korean J. Physiol. Pharmacol. 2016, 20, 201-211. [CrossRef] [PubMed]

33. Wyns, C.; Curaba, M.; Martinez-Madrid, B.; Van Langendonckt, A.; Francois-Xavier, W.; Donnez, J. Spermatogonial survival after cryopreservation and short-term orthotopic immature human cryptorchid testicular tissue grafting to immunodeficient mice. Hum. Reprod. 2007, 22, 1603-1611. [CrossRef] [PubMed]

34. Poels, J.; Van Langendonckt, A.; Many, M.C.; Wese, F.X.; Wyns, C. Vitrification preserves proliferation capacity in human spermatogonia. Hum. Reprod. 2013, 28, 578-589. [CrossRef]

35. Dym, M.; Kokkinaki, M.; He, Z. Spermatogonial stem cells: Mouse and human comparisons. Birth Defects Res. C Embryo Today 2009, 87, 27-34. [CrossRef]

36. Komeya, M.; Kimura, H.; Nakamura, H.; Yokonishi, T.; Sato, T.; Kojima, K.; Hayashi, K.; Katagiri, K.; Yamanaka, H.; Sanjo, H.; et al. Long-term ex vivo maintenance of testis tissues producing fertile sperm in a microfluidic device. Sci. Rep. 2016, 6, 21472. [CrossRef]

37. Wang, P.; Jiang, X.; Jiang, Y.; Hu, X.; Mou, H.; Li, M.; Guan, H. In vitro antioxidative activities of three marine oligosaccharides. Nat. Prod. Res. 2007, 21, 646-654. [CrossRef]

38. Oakberg, E.F. Duration of spermatogenesis in the mouse and timing of stages of the cycle of the seminiferous epithelium. Am. J. Anat. 1956, 99, 507-516. [CrossRef]

39. Clermont, Y. [Kinetics of spermatogenesis in mammals]. Arch. Anat. Microsc. Morphol. Exp. 1967, 56, 7-60.

40. Trommer, H.; Neubert, R.H. The examination of polysaccharides as potential antioxidative compounds for topical administration using a lipid model system. Int. J. Pharm. 2005, 298, 153-163. [CrossRef]

41. Lee, S.R.; Lee, S.J.; Kim, S.H.; Ko, K.S.; Rhee, B.D.; Xu, Z.; Kim, N.; Han, J. NecroX-5 suppresses sodium nitroprusside-induced cardiac cell death through inhibition of JNK and caspase-3 activation. Cell Biol. Int. 2014, 38, 702-707. [CrossRef] [PubMed]

42. Song, J.J.; Chang, J.; Choi, J.; Im, G.J.; Chae, S.W.; Lee, S.H.; Kwon, S.Y.; Jung, H.H.; Chung, A.Y.; Park, H.C.; et al. Protective role of NecroX-5 against neomycin-induced hair cell damage in zebrafish. Arch. Toxicol. 2014, 88, 435-441. [CrossRef] [PubMed]

43. Kim, H.I.; Paik, S.S.; Kim, G.H.; Kim, M.; Kim, S.H.; Kim, I.B. Neuroprotective effect of NecroX-5 against retinal degeneration in rodents. Neuroreport 2016. [CrossRef] [PubMed] 
44. Thu, V.T.; Kim, H.K.; Long le, T.; Thuy, T.T.; Huy, N.Q.; Kim, S.H.; Kim, N.; Ko, K.S.; Rhee, B.D.; Han, J. NecroX-5 exerts anti-inflammatory and anti-fibrotic effects via modulation of the TNFalpha/Dcn/TGFbeta1/Smad2 pathway in hypoxia/reoxygenation-treated rat hearts. Korean J. Physiol. Pharmacol. 2016, 20, 305-314. [CrossRef]

45. Nam, S.Y.; Shin, B.H.; Lee, M.; Lee, S.; Heo, C.Y. NecroX-5 ameliorates inflammation by skewing macrophages to the M2 phenotype. Int. Immunopharmacol. 2019, 66, 139-145. [CrossRef]

46. Thu, V.T.; Kim, H.K.; Long le, T.; Lee, S.R.; Hanh, T.M.; Ko, T.H.; Heo, H.J.; Kim, N.; Kim, S.H.; Ko, K.S.; et al. NecroX-5 prevents hypoxia/reoxygenation injury by inhibiting the mitochondrial calcium uniporter. Cardiovasc. Res. 2012, 94, 342-350. [CrossRef]

47. Voigt, N.; Henrich-Noack, P.; Kockentiedt, S.; Hintz, W.; Tomas, J.; Sabel, B.A. Toxicity of polymeric nanoparticles in vivo and in vitro. J. Nanopart. Res. 2014, 16. [CrossRef]

48. Sadat Tabatabaei Mirakabad, F.; Nejati-Koshki, K.; Akbarzadeh, A.; Yamchi, M.R.; Milani, M.; Zarghami, N.; Zeighamian, V.; Rahimzadeh, A.; Alimohammadi, S.; Hanifehpour, Y.; et al. PLGA-based nanoparticles as cancer drug delivery systems. Asian Pac. J. Cancer Prev. 2014, 15, 517-535. [CrossRef]

49. Henrich-Noack, P.; Nikitovic, D.; Neagu, M.; Docea, A.O.; Engin, A.B.; Gelperina, S.; Shtilman, M.; Mitsias, P.; Tzanakakis, G.; Gozes, I.; et al. The blood-brain barrier and beyond: Nano-based neuropharmacology and the role of extracellular matrix. Nanomedicine 2019, 17, 359-379. [CrossRef]

50. Abd El Hady, W.E.; Mohamed, E.A.; Soliman, O.A.E.; El-Sabbagh, H.M. In vitro-in vivo evaluation of chitosan-PLGA nanoparticles for potentiated gastric retention and anti-ulcer activity of diosmin. Int. J. Nanomed. 2019, 14, 7191-7213. [CrossRef]

51. Jain, D.; Bar-Shalom, D. Alginate drug delivery systems: Application in context of pharmaceutical and biomedical research. Drug Dev. Ind. Pharm. 2014, 40, 1576-1584. [CrossRef] [PubMed]

52. Yang, H.; Li, J.; Patel, S.K.; Palmer, K.E.; Devlin, B.; Rohan, L.C. Design of Poly(lactic-co-glycolic Acid) (PLGA) Nanoparticles for Vaginal Co-Delivery of Griffithsin and Dapivirine and Their Synergistic Effect for HIV Prophylaxis. Pharmaceutics 2019, 11. [CrossRef] [PubMed]

53. Gautier, S.; Grudzielski, N.; Goffinet, G.; de Hassonville, S.H.; Delattre, L.; Jerjme, R. Preparation of poly(D,L-lactide) nanoparticles assisted by amphiphilic poly(methyl methacrylate-co-methacrylic acid) copolymers. J. Biomater. Sci. Polym. Ed. 2001, 12, 429-450. [CrossRef] [PubMed]

54. de Michele, F.; Poels, J.; Weerens, L.; Petit, C.; Evrard, Z.; Ambroise, J.; Gruson, D.; Wyns, C. Preserved seminiferous tubule integrity with spermatogonial survival and induction of Sertoli and Leydig cell maturation after long-term organotypic culture of prepubertal human testicular tissue. Hum. Reprod. 2017, 32, 32-45. [CrossRef] [PubMed]

55. Costoya, J.A.; Hobbs, R.M.; Barna, M.; Cattoretti, G.; Manova, K.; Sukhwani, M.; Orwig, K.E.; Wolgemuth, D.J.; Pandolfi, P.P. Essential role of Plzf in maintenance of spermatogonial stem cells. Nat. Genet. 2004, 36, 653-659. [CrossRef]

56. Kim, J.Y.; Jung, H.J.; Yoon, M.J. VASA (DDX4) is a Putative Marker for Spermatogonia, Spermatocytes and Round Spermatids in Stallions. Reprod. Domest. Anim. 2015, 50, 1032-1038. [CrossRef]

57. Kostova, E.; Yeung, C.H.; Luetjens, C.M.; Brune, M.; Nieschlag, E.; Gromoll, J. Association of three isoforms of the meiotic BOULE gene with spermatogenic failure in infertile men. Mol. Hum. Reprod. 2007, 13, 85-93. [CrossRef]

58. Elmore, S. Apoptosis: A review of programmed cell death. Toxicol. Pathol. 2007, 35, 495-516. [CrossRef]

59. Pryor, W.A.; Stanley, J.P. Letter: A suggested mechanism for the production of malonaldehyde during the autoxidation of polyunsaturated fatty acids. Nonenzymatic production of prostaglandin endoperoxides during autoxidation. J. Org. Chem. 1975, 40, 3615-3617. [CrossRef]

60. Esterbauer, H.; Cheeseman, K.H. Determination of aldehydic lipid peroxidation products: Malonaldehyde and 4-hydroxynonenal. Methods Enzymol. 1990, 186, 407-421.

(C) 2019 by the authors. Licensee MDPI, Basel, Switzerland. This article is an open access article distributed under the terms and conditions of the Creative Commons Attribution (CC BY) license (http://creativecommons.org/licenses/by/4.0/). 